\title{
Improving Students' Reading Ability Using Microsoft Power Point
}

\author{
Aulia Zahroyat, Sujoko, Endang Setyaningsih \\ Teacher Training and Education Faculty, Sebelas Maret University
}

\begin{abstract}
This study is written: (1) to find out whether the use of media Microsoft Power Point can improve students' reading ability (2) to describe what happens when the Microsoft Power Point is applied in teaching reading. The subject was V of one of elementary school in Karanganyar in the academic year of 2013/2014. This is an action research conducted in two cycles. There are two kinds of data: qualitative data and quantitative data. The qualitative data are collected through observation and interview. The quantitative data are collected using test. The research findings prove that media Power Point could improve the students' reading ability in indentifying detailed information in a text, meaning of certain words, and reference. The students' achievement from pre-test score to post-test increased from 61.45 in pre-test, 70.53 in post-test 1 , and 88.29 in post test 2 . Besides, the media also made the teaching and learning process became effective and the students became more focus to the lesson.
\end{abstract}

Key words: media, students' reading ability

\begin{abstract}
Abstrak
Artikel ini ditulis untuk: (1) mengetahui apakah penggunakan media Power Point dapat meningkatkan kemampuan membaca para siswa (2) Mendeskripsikan apa yang terjadi saat Power Point diaplikasikan untuk mengajar membaca. Subyek penelitian ini adalah siswa kelas V di salah satu sekolah dasar di Karangnyar tahun ajaran 2013/2014. Penelitian Tindakan Kelas ini dilaksanakan sebanyak dua siklus. Data kualitatif diperoleh dari observasi dan interview. Data kuantitatif diperoleh menggunakan tes. Hasil penelitian ini membuktikan bahwa penggunaan media Power Point dapat meningkatkan kemampuan membaca siswa dalam mengidentifikasi informasi rinci dalam sebuah teks, arti beberapa kata tertentu, dan rujukan. Nilai yang diperoleh siswa dari pre-test sampai post-test meningkat dari 61.45 di pre-test, 70.53 di post-test 1 , dan 88.29 di post-test 2 . Di samping itu, media juga berhasil membuat proses belajar dan mengajar menjadi efektif dan para siswa menjadi lebih focus pada pelajaran.
\end{abstract}

Kata kunci: media, kemampuan membaca siswa 
English as a foreign language in Indonesia is introduces since Elementary School. It is expected that when the children grow up, they are able to use English in the global communication.

There are four skills that the students have to master, listening, reading, speaking, and reading. "Reading ability is activities that readers use to construct meaning from a text." (Anderson et al. 1991, Devine 1988a, Hosenfeld et al 1981 in Aebersold and Field, 1997: 76). The students read almost every day in every occasion. They read newspaper, magazine, map, or manual instruction. Therefore, mastering reading ability for students is a must.

By teaching reading, the teachers facilitate the students to learn new words. "Before children begin to learn to associate the written form with speech, they need to learn the vocabulary, grammar, and sound system of the oral." (Pang et al, 2003: 8).

Teaching reading is difficult, because it requires creativity from the teacher to provide a good situation and condition when teaching and learning process is conducted. The teacher needs to use interesting technique to improve the students' reading comprehension.

The writer interviewed the teacher dealing with class situations and teaching and learning process. It was found that the teacher had never used media to teach English but LKS.

After interviewing some students, the result showed that the English teaching and learning was boring because the teacher did not use any special media for teaching reading. She usually used textbook to build students knowledge. The 
students did not want to pay attention because the class activity was not interesting and monotonous.

Based on observation at class, the writer found that the students looked bored. Some of them even chatted with their friends and did not pay attention to the teacher. When the teacher asked them to answer questions, only few of them answered it. From those few students, most of them got difficulties in identifying detailed information, meaning of words, and reference in from the text. The teacher read the text once and sometimes pointed some students to read loudly without giving any correction for mispronounce words. During the lesson, the teacher only used LKS to explain the material. She did not use interesting media to present the material. Besides, she also did not give enough exercises to check students' understanding.

To make teaching and learning English in elementary successful, teacher have to use additional media beside LKS or students' workbook. At least, the media can attract the students' attention to the lesson. Balancing to globalization era, electronic media can be one way to teach the lesson. One of available media in school is power point presentation. According to Cashman (2008:9), "Power Point is a multimedia lecture presentations system that provides slides for each chapter." It is a processing program that combines text and numbers that have gathered and put up a slide with a picture and a professional touch to satisfy the demand of audience." Most of users including elementary teacher do not optimize this program yet. Nevertheless, Power Point actually provides its users to insert pictures, videos, music, and graphic to make the presentations more attractive. Hence, those findings become a basic of reason 
why the writer wants to conduct a research of using a media to improve the students' interest in teaching reading ability, such as using a computer, especially Microsoft Power Point.

Microsoft Power Point can be used as one of alternative media for teaching process in the class. Teacher can present their lesson attractively by using designed presentation. Consequently, it can make the students attracted to learn English. Furthermore, the atmosphere of the class can be more conducive. The teacher should make a comprehensive and interesting material in order to make the students always focus on the lesson so that the goal of learning can be reached.

This article discusses the findings of an action research at one of elementary school in Karanganyar which has the following goals: (1) to find out whether the use of media Microsoft Power Point can improve students' reading ability (2) to describe what happens when the Microsoft Power Point is applied in teaching reading.

\section{METHOD}

This action research was conducted at one of elementary school in Karanganyar from April to Juni 2014. The subject of the research was the students of class V of one of elementary school in Karanganyar in the academic year of 2013/2014.

Action research is generally admired by the educational researchers for practice, practitioner researchers are acknowledged in the research literature as original, significant and important contributions to educational theory (Whitehead and McNiff, 2006: 156). Teaching learning process is done to get the main goal of 
learning which is supported by several factors; they are factors from the subject and the instrument of learning itself. To optimize the applied role, all the subject of learning need to know whether the learning process goes well or not. Action research is applied to overcome the problem in learning process from the beginning to the end of leaning.

Nunan (1992: 18) also argues that action research has a distinctive feature that is affected by planned changes have the primary responsibility for deciding on course of critical informed action in which seem likely to lead to improvement, and for evaluating the result of strategies tried out in practice. Through the action research also, the teacher can use an innovation to improve the teaching learning process. Since, after the teacher knows the lack of the way or others factor in delivering the material to the students, she is encouraged to find another better way to have the better achievement. To get the best achievement in learning, the entire subject should take part during the learning process. If there is a problem in learning process, all participants have to get involved in repairing process.

After taking action of the research, the researcher needs to observe whether the research has shown the progress or not. If it needs more implementation of the planning, the research may conduct the next cycle, by considering the unsolved problems.

The research is conducted in two cycles. This action research consisted of planning, action, observation, and reflection. There are two types of data, they are, qualitative data that are obtained by conducting interview, observation, questionnaire; 
meanwhile quantitative data are obtained from the students' scores of pre-test and post-test.

\section{RESEARCH FINDINGS AND DISCUSSIONS}

In this research the writer implemented Power Point as a media to improve student's reading ability. The research was conducted in two cycles. There were three meetings held in each cycle. The first meeting included drilling and practice, second meeting included exercise to find detail information, and third meeting included exercise about reference. The first step done before conducting any action was planning the action. This was done by preparing lesson plan and materials. Therefore, all that had been planed was implemented in the class. From the observation, the writer evaluated and reflected the result. By considering the evaluation and reflection, it could be decided whether the research was continued to cycle 2 or not.

To observe the result of the action done in cycle 1 , the writer used some techniques: test, interview, and observation. The writer conducted the post-test at the end of cycle 1 in order to measure how far the improvement that had been made by the students made was. The improvement of the students' achievement could be seen in the mean score of the test. The writer also interviewed students. The interview was given to know how far the action influenced the students' ability. The next technique was observation. It was done during the teaching and learning process and the data was written in the field note. 
From observing the teaching and learning process in the cycle 1, the writer found that media Power Point could motivate the students in learning English, especially in learning reading text. It could be seen from their activeness during the lesson. The class could be controlled although sometimes they were still noisy during the lesson.

Besides, the writer also still found the following problems: 1) students got difficulties in identifying detailed information of paragraph; 2) students did not understand about reference.

While the class situation in reading class showed: 1) a number of students were passive; 2) few of group students relied on the smartest member; 3) few students were noisy; 4) few students were afraid to answer the questions when the writer asked them.

It could be summarized that the cycle 1 showed improvement of students' reading ability but it was still far from expected result. For the better improvement, the writer planned the cycle 2 .

In order to overcome those problems appeared in the cycle 1, the writer continued the learning activity into cycle 2 . The writer maximized the use of power point to deliver the material to the students through providing more brainstorming before starting the lesson, such as by providing more pictures to find the meaning and by using more hyperlinks in the text.

To observe the result of the action done in cycle 2, the writer used some techniques which were the same as the technique used in cycle 1: test, interview, and 
observation. The writer conducted the final post-test at the end of cycle 2 in order to know the students' improvement. The improvement of the students' achievement could be seen from the mean score of the test. The next technique was interview in order to know how far the action influenced the students in learning the lesson. The observation was done during the teaching and learning process.

From observing the teaching and learning process in the second cycle, the writer found the use of Power Point in motivating the students in learning English. It could be seen from the students' activeness during the lesson. When the students found difficult words or unfamiliar terms, the writer used hyperlink to facilitated students' comprehension about those difficult vocabularies.

After cycle 2 in teaching using media Power Point, the students became focus and attracted to the material. The class also could be conttolled.

Table 1 The Improvement of Reading Ability

\begin{tabular}{cccc}
\hline Aspect & Pre-test & Post-test 1 & Post-test 2 \\
\hline Detail info & 25.93 & 26.80 & 34.18 \\
\hline Meaning & 16.33 & 29.29 & 35.83 \\
\hline Reference & 18.33 & 21.00 & 26.67 \\
\hline
\end{tabular}

Besides, the class situation showed the progresses as well, those were: 1) the students were interested in the slides of Power Point. A number of students were responding more actively to the writer's questions; 2) the students became more enthusiastic in learning English; 3) the students were diligent to do their work; 4) the media Power Point was successfully applied to deliver the material to the students 
because the media provided pictures and sounds. They became more focus to the material; 5) the students paid attention to the teacher's explanation.

By using media Power Point, the class was easy to be conditioned and became conducive. Various colorful pictures could attract students' attention. The media helped the students to understand about the materials. The students were more motivated to the lesson. The students were no longer chatted with their friends. The class was no longer noisy. It made the classroom situation became more conducive. Besides, the students' manner changed during the lesson. In the beginning, the students were not respect to the writer. But they became friendly and cheerful day by day.

Furthermore, there were some positive progresses shown by some students who were ashamed in the class. They were not confident to answer the questions. But, through the meetings, those ashamed students' became more confident in answering the questions. They became more active in joining the teaching and learning activities.

Based on the description of those two cycles, the writer concluded that media Power Point is the effective way to improve the students' reading ability. It is proven through these following discussions: (1) Students' reading ability improved after using Power Point as a media. Williams (1996:21) says the objective of reading for the students is that they should be able to learn the content from reading. It means that the students are able to pick out the relevant information, evaluate arguments and evidence, and distinguish between the main points and the details. Gagne in Musfiqon 
(2012:27) states that media are many kinds of components in students' environment that can stimulate them to study. The writer applied the media because it can facilitate teaching and learning activities. Using Power Point can help the students to get clear understanding about material because they can see the picture of what they learn through Power Point. Power Point also can increase students' interest in learning. It happens because Power Point can provide the students with colorful pictures and sound to show them the correct pronunciation of the text. Therefore, the students' motivation is aroused by using media Power Point in learning.

Before treatment, the students' mean score is under the passing grade $(61.45<$ 75.00). After actions, the students score is increased 70.53 in the second post-test 1. But, the score significantly increased become 88.29 in the second post-test 2 . In addition, every student's skills showed improvements as well, such as: finding the detail information increased from 25.93 in pre-test, 26.80 post-test 1 , and 34.18 posttest 2; identifying meaning of words increased from 16.33 in pre-test, 29.29 post-test 1 , and 35.83 post-test 2 ; and identifying the reference increased from 18.33 in pretest, 21.00 post-test 1 , and 26.67 post-test 2 .

It can be concluded that the use of media can improve students' reading ability of class V in SDN 02 Delingan Karanganyar. The student could find out the detailed information by themselves. They also could understand several new words. They knew how to identify reference as well. It was also proven by their mean score which increased from pre-test until the post-test. 
(2) Before the research process, the writer found that the students' reading ability was low; they found difficulties in identifying meaning of certain words, identifying the detail information of a text, and identifying reference. The problems also came from class situation such us: the students' got bored during the lesson, they were passive, and they chatted with their friends.

The teacher only asked the students to read the text directly without discussing what the text about. So the students didn't get the point of the material. The students also found difficulties in identifying meaning of words. It is caused by the lack of vocabularies. Some students also did not have dictionary to help them find the meaning of words in text. The teacher did not give exercise emphasized on identifying meaning of words.

Related to the class problems, they were less interested to the lesson so the class situation was passive. There were no pictures to help the students understand to what the text means. It was also unattractive media to get students attention. Accordingly, the class situations became noisy because many students chat with friends. Thus, media could be used to solve those problems.

According to the interviews with the English teacher, she said that the students have difficulties in identifying reference. The teacher added that the students cannot identify the reference because they forget the manner of possessive pronouns however the teacher have given strategies about how to identify reference correctly. Thus, media could be used to solve those problems. 
Power Point is well known among professionals including academician to present material, information, and data. But, most users including elementary teacher do not optimize this program yet. Nevertheless, Power Point actually provides its users to insert pictures, videos, music, and graphic to make the presentations more attractive. By this, the writer optimized the use of Microsoft power point to improve students' motivation.

There are some advantages of using media in teaching-learning process. Those are: a) To increase the learners' motivation. b) To avoid the learners bored. c) To make the learners easy to understand the instructional material. d) To make the teaching learning process more systematic.

Therefore, Power Point is helpful application which facilitates the teacher to present the lesson in more attractive way by modifying the appearance of English lesson. As a result, the students now understand how to find detail information, identify the meaning of words, and identify reference well.

\section{CONCLUSIONS AND SUGGESTIONS}

The first point to be concluded is the use of Power Point combined with an appropriate teaching method can improve the students reading ability and classroom situation. Before treatment, the students were noisy and passive in the class. They walked around the class and chatted with the others students. After presenting the material using Power Point by giving interesting slides, the students' behaviors changing became active and focus on the lesson. There are some improvements 
achieved by the students after the research finished. The writer applied the media in teaching and learning activities because media can solve the lack of the students' experiences in learning using media.

The second point is the students' score improved; the mean score in the pre test was under the passing grade $(61.45<75.00)$. After actions, the students score was increased 70.53 in the second post-test 1 . But, the score significantly increased became 88.29 in the second post-test 2 . In addition, every student's skills showed improvements as well, such as: finding the detail information increased from 25.93 in pre-test, 26.80 post-test 1 , and 34.18 post-test 2 ; identifying meaning of words increased from 16.33 in pre-test, 29.29 post-test 1 , and 35.83 post-test 2 ; and identifying the reference increased from 18.33 in pre-test, 21.00 post-test 1 , and 26.67 post-test 2 .

Power Point provides its users to insert pictures, videos, music, and graphic to make the presentations more attractive. There are some advantages of using media in teaching-learning process. Those are: 1) to increase the learners' motivation, 2) to avoid the learners bored, 3) to make the learners easy to understand the instructional material, and 4) to make the teaching learning process more systematic.

It can be concluded that the use of media can improve students' reading ability of class V in SDN 02 Delingan Karanganyar. The student could find out the detailed information by themselves. They also could understand several new words. They knew how to identify reference as well. It was also proven by their mean score which increased from pre-test until the post-test. 
In additional, the situation of the class when the teacher implemented Power Point media in reading activity is able to make students not to be noisy during the teaching and learning process in the classroom. The students also become active and students pay attention toward the teachers' explanation.

In conducting the Classroom Action Research (CAR), the writer encouraged the students to enjoy the activities during the lesson. It was proven that using media Power Point in teaching reading is effective and help the teacher manage the class easily. Teaching using media Power Point has some positive side such as most of student become active, they pay attention to the teacher explanation, become confident time to time, and the result of their test has increased.

Based on the conclusion above, media Power Point can be applied in teaching and learning process to improve students' reading ability. By designing Power Point slide, teachers can optimize the use of Power Point by adding some picture and audio that can attract the students' attention. Besides, the students become focus and understand the material easily. The use of Power Point can be developing to achieve all the reading ability's' aspect. It also easy application to operate even by all teachers.

After concluding the result of the study, the writer would like to recommend some suggestion. Teacher should improve their creativity in teaching English, for example they can conduct teaching and learning activities using media Power Point to attract students' interest and motivation. The teacher also should prepare several tools 
to support the use of Power Point, so when the teacher teaches the students in the class, the process of teaching and learning will be optimal and efficient.

The institution should support the classroom by providing facilities that support the teaching and learning process. Due to the use of Power Point, the school should have white screen so that the slide of Power Point can be clearly see.

Besides, the writer hopes that the other researchers get inspiration to do research about kinds of technology which can contribute to students. The writer wishes that the other researchers take another subject besides Power Point. So that, the result of the research can contributes to the teaching and learning English.

\section{BIBLIOGRAPHY}

Aebersold, Jo Ann \& Field, Marry Lee. (1997). From reader to reading teacher. Cambridge: Cambridge University Press.

Cashman, Shelly. (2008). Microsoft Power Point 2007 Introductory Concepts and Techniques. Boston: Nelson Education Ltd.

McNiff, Jean \& Jack Whitehead. (2006). Action Research Living Theory. Oxon: Routledge. London: SAGE Publications Ltd.

Musfiqon, HM. (2012). Pengembangan Media \& Sumber Pembelajaran. Jakarta: PT. Prestasi Pustakaraya.

Nunan, David. (1998). Research methods in language teaching. New York: Cambridge University Press.

Pang, Elizabeth, Angaluki Muaka, Elizabeth B. Bernhardt, \& Michael L. Kamil. (2003). Teaching Reading. Chicago: IAE Educational Practices Series University of Illinois.

William, Eddie. (1996). Reading in language classroom. London: Phoenix EL. 